\title{
Urwindin ja Bahtinin kohtaaminen
}

Brian Kennedy (ed.): Voicing Bo Carpelan: Urwind's Dialogic Possibilities. Nykykulttuurin tutkimuskeskuksen julkaisuja, 126. Jyväskylä: Nykykulttuurin tutkimuskeskus, 2020, 206 s.

Voicing Bo Carpelan on Carpelanin Urwind-romaaniin (1993, suom. Alkutuuli) keskittyvä artikkelikokoelma. Kirja juontaa juurensa vuoden 2005 kansainvälisen Bahtin-konferenssin paneeliin, jossa neljä tutkijaa tulkitsi Carpelanin Finlandia-palkittua romaania Bahtin-lasien lävitse. Kokoelma on ensimmäinen englanninkielinen Carpelanin tuotannolle omistettu tutkimusantologia. Carpelanin lyriikkaa ja proosaa on käännetty englanniksi suhteellisen paljon, kääntäjänä brittiläinen kääntäjä ja kriitikko David McDuff. Ennen Voicing Bo Carpelan -kokoelman ilmestymistä englanninkielistä tutkimusta Carpelanin tuotannosta on kuitenkin ollut vähänlaisesti saatavilla, ainoastaan yksittäisiä tutkimusartikkeleita.

Teoksessa on huomioitu hyvin lukijat, jotka eivät tunne entuudestaan suomalaista kirjallisuudenhistoriaa saati Carpelanin tuotantoa. Kokoelman toimittaja, kanadalainen kirjallisuudentutkija Brian Kennedy, asemoi johdannossaan Urwindin tekemällä selkoa suomalaisesta modernismista ja sen suhteesta kansainväliseen modernismiin. 1990-luvulla ilmestynyt modernistinen romaani näyttäytyy varsinkin angloamerikkalaisen modernismin näkökulmasta auttamattomasti jälkijättöiseltä. Kennedy kysyykin provosoivasti, miksi Carpelania pitäisi lukea. Hän toivoo artikkeleiden vastaavan kysymykseen ja rohkaisevan lukijoita Urwindin ja Carpelanin muiden teosten pariin.

Kokoelman lähtöasetelma, jossa Urwindiä luetaan Bahtinin teorioiden ja käsitteiden kautta, on kaikkea muuta kuin ilmeinen. Bahtinin kiinnostuksen kohteena ei ollut modernistinen proosa (mikäli Dostojevskia ei lasketa modernistiksi), eikä Urwindin kaltainen päällisin puolin yksiääninen minä-kerronta istu Bahtinin käsityksiin romaanikerronnasta. Stephen Souris osoittaa kuitenkin artikkelissaan, että Urwindissä on dialogisia aineksia usealla tasolla. Yhteiskunnan eri kerrostumat ja äänet kohtaavat talossa, jossa romaanin kertoja-päähenkilö asuu. Myös romaanin lukuisat viittaukset kirjallisuuteen, musiikkiin ja kuvataiteisiin luovat moniäänisyyttä samoin kuin montaasimainen sommittelu, jossa toisiaan seuraavat luvut kuvaavat vastakkaisia asenteita ja tunteita. Lisäksi realistiseen tasoon murtautuu tuon tuostakin groteskeja, fantastisia aineksia, joita Souris tarkastelee karnevalismin kehyksessä.

Siinä missä Sourisin luenta Urwindistä sisältää melko vähän varauksia, Erkki Vainikkala tarkastelee Carpelanin proosarunoutta lähestyvää romaania bahtinilaisena "rajatapauksena". Hän käy läpi Bahtinin teorioita ja käsitteitä eri ajoilta ja pohtii kriittisesti niiden soveltuvuutta Urwindin tarkasteluun tuoden 
esille teorian ja teoksen välisiä hankauskohtia. Vainikkalan artikkeli on teoreettisessa terävyydessään kokoelman antoisin.

Dialogisuuden jälkeen kokoelmassa hyödynnetään Bahtinin käsitteistä eniten kronotooppia. Kennedyn oman huomion kohteena ovat muutosta kuvaava kynnyksen kronotooppi ja Urwindin päähenkilön, Daniel Urwindin, keski-iän kriisi, jonka ero vaimosta laukaisee. Kennedyn artikkeli on esimerkki siitä, kuinka ulkopuolinen näkökulma voi tuoreuttaa teoksen tulkintaa. Kennedy vertaa Danielin kriisikokemusta Septimus Warren Smithin mielen järkkymiseen Virginia Woolfin Mrs. Dallowayssa (1925) ja Charlotte Perkins Gillmanin "The Yellow Wallpaper" -novellin (1892) kertojan mielentilaan. Kolmas vertailukohta on American Beauty -elokuvan (1999) päähenkilö Lester Burnham, joka keski-iän kriisissään näkee eroottisia päiväunia teini-ikäisen tyttärensä ystävättärestä. Varsinkin viimeinen vertailukohta on yllättävä ajatellen kirjoihin uppoutunutta, hieman veretöntä Danielia, joka vaikuttaa 53 ikävuottaan vanhemmalta. Vertailu osoittaa kuitenkin, että Urwindiä voi lukea paitsi modernistisen korkeakulttuurin myös ilmestymisaikansa populaarikulttuurin kontekstissa.

Pauli Tapani Karjalainen sivuaa kronotoopin käsitettä tarkastellessaan paikan problematiikkaa Urwindissä, mutta hänen teoreettinen kehyksensä painottuu humanistiseen maantieteeseen. Nanny Jolmakaan ei narratologisesti suuntautuneessa artikkelissaan hyödynnä Bahtinin teorioita, mutta aiheensa puolesta artikkeli, jossa tarkastellaan ajan kokemista ja muistamista Urwindissä ja Berg-romaanissa (2005, suom. Kesän varjot), sopii hyvin kokonaisuuteen. Kokoelman viimeisessä artikkelissa Catherine Maloney lukee Urwindiä filosofisena tekstinä soveltaen Bahtinin ajatusta luovasta ymmärtämisestä, jolla on yhtymäkohtia Milton Bennettin kulttuurien väliseen dialogiin. Peter Hitchcockin jälkisanoissa pohditaan vielä yhteenvetona Bahtinin dialogisuuden toteutumista Urwindissä. Kannesta kanteen luettuna kokoelman keskittyminen yhteen romaanin ja yhteen teoreetikkoon tuottaa väistämättä päällekkäisyyttä, mikä ei tietenkään haittaa lukijaa, joka lukee kerrallaan vain artikkelin tai kaksi.

Artikkelikokoelman tekoprosessi on ollut pitkä. Carpelanilta oli alun perin tarkoitus tilata runo kirjan motoksi, mutta hän kuoli ennen pyynnön toteuttamista. Kirjoittajiin kuulunut Roger Holmström ei ilmeisesti ennättänyt viimeistellä tekstiään täysimittaiseksi artikkeliksi ennen kuolemaansa 2016. Luonnosmaiseksi jääneeseen artikkeliin sisällytetyt katkelmat Holmströmin teoksesta Vindfartsvägar: Strövtåg i Bo Carpelans Urwind (1998) tarjoavat kuitenkin tervetulleita välähdyksiä hänen Urwind-tulkinnoistaan.

Voicing Bo Carpelan -kokoelmaa vaivaa monen muun kokoelman lailla epätasaisuus. Teos puoltaa kuitenkin paikkansa tarjotessaan tutkimusta Carpelanin tuotannosta suomea ja ruotsia taitamattomille lukijoille. Teosta arvioidessa ei myöskään sovi unohtaa inspiroivaa näkökulmaa, joka syntyy Urwindin ja Bahtinin kohtaamisesta.

\section{Anna Hollsten}

